\title{
Comparative population dynamics of four fiddler crabs (Ocypodidae, genus Uca) from a North Brazilian mangrove ecosystem
}

\author{
Volker Koch $^{1, *}$, Matthias Wolff ${ }^{2}$, Karen Diele ${ }^{2}$ \\ ${ }^{1}$ Universidad Autónoma de Baja California Sur, Departamento de Biología Marina, Apartado 19-B, Carretera al Sur km 5.5, \\ 23080 La Paz, Baja California Sur, Mexico \\ ${ }^{2}$ Zentrum für Marine Tropenökologie, Fahrenheitstrasse, 28359 Bremen, Germany
}

\begin{abstract}
Abundance, biomass, population structure, growth, mortality and reproduction of 4 fiddler crabs (Uca cumulanta, U. maracoani, U. rapax and $U$. vocator) were studied in the Caeté mangrove estuary, North Brazil, to understand their life history strategies and species distribution in the mangrove forest. Three zones were sampled in the mangrove ecosystem: high intertidal forest (F), small creeks running through the forest (SC), and open mud banks of large tidal creeks (LC). Significant differences between zones were found in silt/clay, water and organic content of the sediment. Species zonation was pronounced: U. rapax and U. vocator were restricted to the high intertidal forest (differing preferences for organic and water content of the sediment probably allows these 2 species to coexist); $U$. cumulanta and $U$. maracoani were mostly restricted to the mid and low intertidal (the sunny mud banks of large creeks were completely dominated by the latter, probably due to its greater tolerance to high temperatures). Fiddler crab biomass was highest in LC, followed by $\mathrm{F}$ and SC $\left(72.9,19.5\right.$, and $10 \mathrm{~g} \mathrm{~m}^{-2}$, respectively), while abundance was highest in LC, followed by SC and $\mathrm{F}\left(79.1,69.2\right.$, and 59.3 ind. $\mathrm{m}^{-2}$, respectively). Population structure of all species was strongly skewed towards the smallest size classes, and sex ratios were 1:1 in $U$. maracoani and $U$. vocator, with significantly more females in $U$. cumulanta and $U$. rapax. All fiddler crabs studied were fast-growing, and had short life spans and high mortality rates. Von Bertalanffy growth parameters, growth performance, and total mortality rates were calculated for all species. $L_{\infty} K$, and Munro's $\phi^{\prime}$ ranged from $11.1 \mathrm{~mm}$ carapace width (CW), 4.24 and $1.7 \mathrm{yr}^{-1}$ in $U$. cumulanta females up to $35.2 \mathrm{~mm} \mathrm{CW}, 2.03$ and $3.2 \mathrm{yr}^{-1}$ in $U$. maracoani males. Total mortality rates $(Z)$ varied between 4.9 and $10.1 \mathrm{yr}^{-1}$, with females having generally 15 to $20 \%$ higher mortality rates than males, except for $U$. cumulanta. All species except $U$. vocator reproduced mainly during the dry season, but breeding was always prolonged and sometimes year-round, e.g. in $U$. rapax, 1 of the 2 species occurring in the forest. The second forest species, $U$. vocator, had a clear spawning peak towards the end of the rainy season and temporal separation of reproduction may also promote coexistence of the 2 species.
\end{abstract}

KEY WORDS: Uca spp. · Fiddler crabs · Population dynamics · Growth · Mortality $\cdot$ Reproduction · Zonation $\cdot$ Sympatry $\cdot$ Brazil $\cdot$ Mangrove epibenthos

Resale or republication not permitted without written consent of the publisher

\section{INTRODUCTION}

Fiddler crabs are among the most conspicuous organisms in many intertidal ecosystems including mangrove forests, salt marshes, mud and sand flats. They range from tropical to warm temperate areas, with the highest species diversity found in the Americas (Crane
1975, Montague 1980). Their distribution and zonation in the intertidal mostly depends on abiotic factors such as shore level, salinity, temperature and sediment grain size and organic content (e.g. Gerlach 1958, Macnae 1968, Crane 1975, Icely \& Jones 1978, Frith \& Brunnenmeister 1980). Although shore level and temperature regime have been considered most influential for the 
distribution of intertidal crabs in general (e.g. Macnae 1968, Warner 1969, Jones 1984, Frusher et al. 1994), sediment characteristics such as silt/clay and organic content are especially important for deposit-feeders such as Uca spp. (Altevogt 1957, Miller 1961, Icely \& Jones 1978, Frith \& Brunnenmeister 1980, Robertson \& Newell 1982a,b, Jaramillo \& Lunecke 1988).

Fiddler crabs are an important link to higher trophic levels in intertidal and shallow water food webs. Koch $\&$ Wolff (2002) reported that detritivorous crabs (>95\% fiddler crabs) account for almost $90 \%$ of total benthic macrofauna production in the Caeté mangroves (intertidal). Wolff et al. (2000) showed that fiddler crabs are among the most important prey in the food web of the Caeté mangroves, where they form part of the diet of many crustaceans, birds, fish and mammals. By converting a substantial part of bacterial production directly into 'bite-sized' food items for larger predators, energy transfer via the 'fiddler crab pathway' is highly efficient.
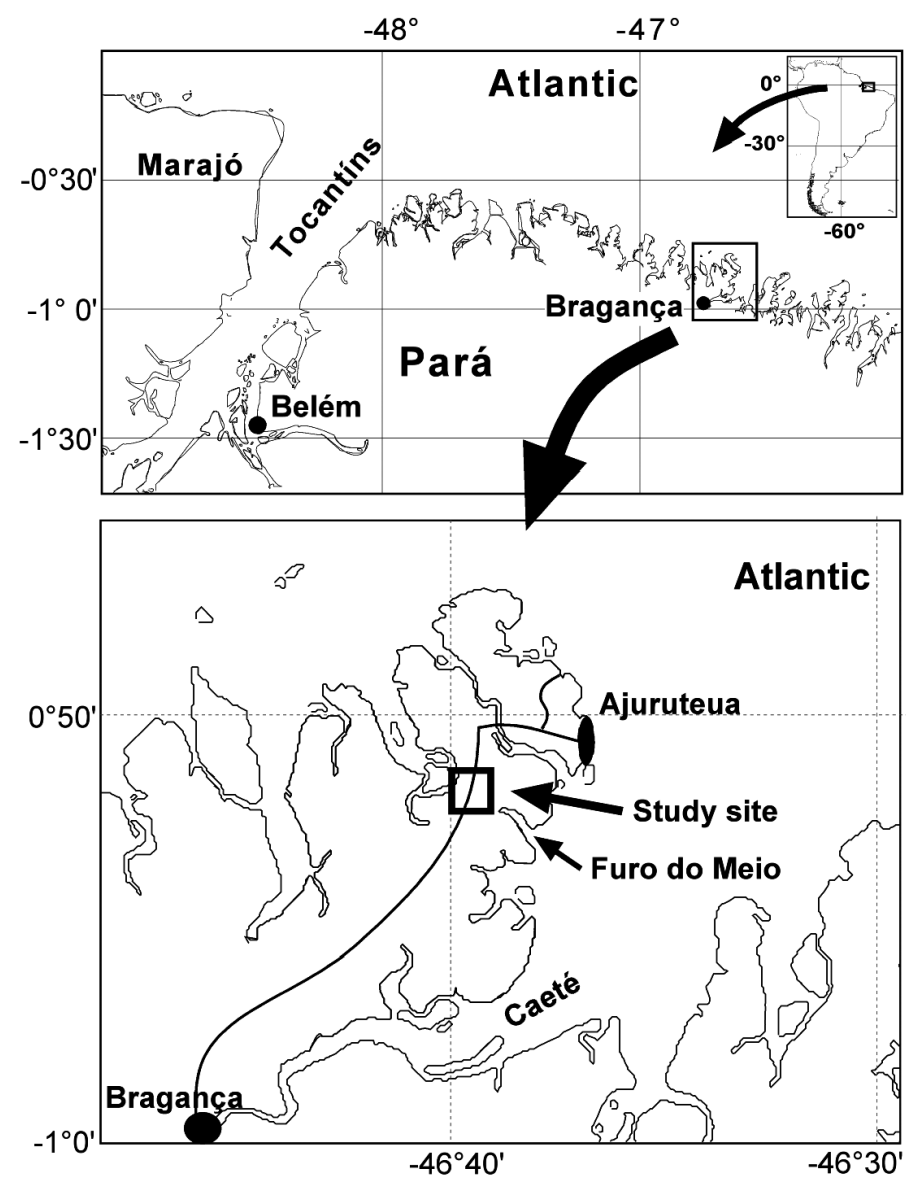

Fig. 1. The study area. The upper part shows the North Brazilian coastline east of the Tocantins, the lower part shows the mangrove peninsula north of Bragança with inset indicating study site at the Furo do Meio
While the important ecological role of fiddler crabs is evident, few studies (e.g. Shanholtzer 1973, Colby \& Fonseca 1984) have focused on their population dynamics (i.e. growth, mortality and recruitment rates). Studies on secondary production of fiddler crabs show that they have high turnover and production rates (Teal 1962, Macintosh 1984, Koch 1999, Koch \& Wolff 2002), but there is very little information on the biological processes that determine their population size and productivity. Therefore, the overall objective of this study was to investigate the population dynamics and spatial distribution of the dominant fiddler crabs in the Caeté estuary to better understand their life history strategies and how the species use different zones in the mangrove ecosystem.

Specifically, we asked the following questions: (1) How are the species distributed in the mangrove forest? (2) What is their relative and absolute abundance and biomass in the mangrove ecosystem? (3) How do growth and mortality rates differ between the 4 species? (4) What are the main breeding and recruitment seasons and how do female reproductive traits differ among species?

\section{MATERIALS AND METHODS}

Study area. The study area is located on a peninsula on the western shore of the Caeté estuary north of Bragança, about $200 \mathrm{~km}$ east of Belém in North Brazil (Fig. 1). The mangrove cover on the peninsula amounts to about $140 \mathrm{~km}^{2}$, the tidal range in the area is 3 to $5 \mathrm{~m}$. Numerous channels and creeks cut through the peninsula. The largest part of the mangrove forest is situated above the mean high tide level and is only flooded during spring tide days. Red (Rhizophora mangle) and black (Avicennia germinans) mangroves dominate, the white mangrove (Laguncularia racemosa) is the least common species and can often be found at disturbed sites (Thüllen 1997, Mehlig 2001). The region receives approx. $2500 \mathrm{~mm} \mathrm{yr}^{-1}$ of rain, mostly between January and June. Salinity oscillates correspondingly between $<10$ PSU during the rainy season to 39 PSU at the end of the dry season. Average air $\left(24\right.$ to $\left.28^{\circ} \mathrm{C}\right)$ and water $\left(27\right.$ to $30^{\circ} \mathrm{C}$ ) temperatures vary little over the year, with lowest values occurring after heavy rainfalls (INMET 1992, MADAM unpubl. data). The study site was located at the Furo do Meio, a large creek in the central part of the peninsula. For further details, see Koch (1999), Wolff et al. (2000) and Koch \& Wolff (2002).

Field sampling. The study site was subdivided into 3 zones: high intertidal forest (F), small, shaded creeks within the forest (SC) and the open mud banks of large creeks (LC). The area of each zone varied between 1.5 (SC) and 4 ha $(F)$. At each zone, 8 replicate samples 
were taken in intervals of $6 \mathrm{wk}$ over a period of $12 \mathrm{mo}$ (10 mo in SC). Enclosure quadrats were made with acrylic glass plates of $70 \times 20 \mathrm{~cm}$ that were put together to enclose an area of $70 \times 70 \mathrm{~cm}\left(0.49 \mathrm{~m}^{2}\right)$. The quadrats were set up during spring high tides when the mangrove forest was flooded. This ensured that only specimens that actually inhabited the sampled area were caught, because fiddler crabs retreat to their burrows during tidal inundation. Sampling in all 3 zones started after the tide had receded. Each enclosure quadrat was usually sampled 2 to 3 times to ensure complete removal of crabs. Specimens were removed from the surface and dug up by hand. Crabs were taken to the laboratory, frozen at $-20^{\circ} \mathrm{C}$ and later identified, sexed and checked for presence of eggs. Carapace width (CW) of each specimen was measured to the nearest $0.1 \mathrm{~mm}$ under a dissection microscope with a measuring eyepiece (for large individuals, callipers were used) and fresh mass weighed to the nearest $0.01 \mathrm{~g}$.

Growth. The growth of the 4 fiddler crab species was measured in in situ cages (Fig. 2) in intervals of $6 \mathrm{wk}$ from July 1997 to February 1998. Cages were built for each species in its preferred zone. When the cages were constructed, special consideration was given to the following: (1) wooden boards reached $60 \mathrm{~cm}$ into the sediment to prevent crabs from digging their way out (or in); (2) acrylic glass plates were fixed on top of the cages that also prevented crabs from leaving or entering; (3) a fence of mangrove stems was collocated around each cage (to a depth of about $1 \mathrm{~m}$ ) to prevent large mangrove crabs Ucides cordatus from burrowing into the cages.

Prior to the experiment all animals were removed from the cages in the same way the crabs were sampled in the enclosure quadrats. Two to 3 visits were sufficient to remove all animals and no further crabs were found when checking 2 wk later. Each cage compartment was then stocked with animals of both sexes of 1 size class only $( \pm 0.2 \mathrm{~mm})$ at natural densities, thus creating 'artificial cohorts' (for initial sizes, see Fig. 7). Crabs were recaptured and measured to the nearest $0.1 \mathrm{~mm}$ CW every 6 to $8 \mathrm{wk}$ and returned to the cages afterwards.

The von Bertalanffy growth function (VBGF) (von Bertalanffy 1934, Ricker 1975) was used to describe the growth of the crabs:

$$
L_{t}=L_{\infty} \cdot\left(1-\mathrm{e}^{-\left(K \cdot\left(t-t_{0}\right)\right.}\right)
$$

where $L_{t}$ is the length at time $t_{1} t_{0}$ is the age at zero length and $K$ is the curving parameter of the growth function. The parameters were calculated using the Munro plot (Munro 1982):

$$
K_{\left(t_{\mathrm{i}}+1-t_{\mathrm{i}}\right)}=\ln \left(L_{\infty}-L_{\mathrm{i}}\right)-\ln \left(L_{\infty}-L_{\mathrm{i}+1}\right)
$$

where $L_{\mathrm{i}}$ and $L_{\mathrm{i}+1}$ are the lengths at times $t_{\mathrm{i}}$ and $t_{\mathrm{i}+1}$

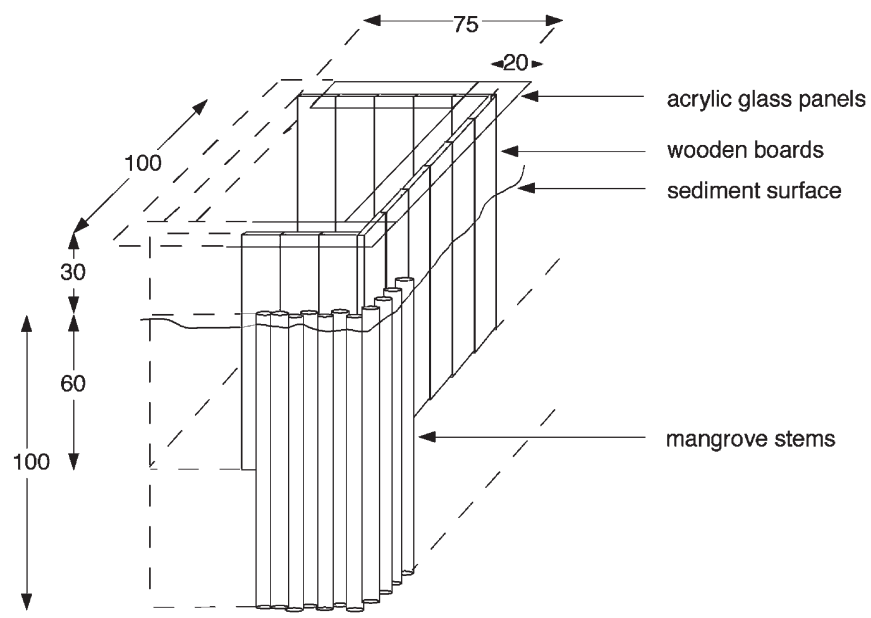

Fig. 2. Cage compartment used for determining growth rates of Uca spp. All measurements are given in $\mathrm{cm}$

respectively, and $K$ and $L_{\infty}$ are as described above. As specimens could not be recognized individually, each pair of lengths represents the arithmetic mean of all males or females of 1 size class in a cage compartment. The optimum combinations of $K$ and $L_{\infty}$ values were obtained by varying $L_{\infty}$ until the coefficient of variation for $K$ was minimized. Data analysis was done with FiSAT (Gayanilo et al. 1994). $t_{0}$ was set to zero as no data for larval and early postlarval development time was available that would have allowed for the estimation of absolute age for the species under study. Seasonal growth oscillation in all species was small (amplitude of the growth curve: $\mathrm{C}<0.1$, Pauly \& Gaschuetz 1979), therefore the normal VBGF was used. Munro's $\phi^{\prime}$ (Pauly \& Munro 1984) was used to calculate the growth performance of the fiddler crabs:

$$
\phi^{\prime}=\ln K+2 \cdot \ln L_{\infty}
$$

This index allows for comparison of the growth potential of different species and thus serves to evaluate patterns along latitudinal gradients and/or among taxonomic groups.

Mortality. Length-converted catch curves (Ricker 1975, Sparre et al. 1989) were used to calculate total mortality rate $(Z)$ for males and females of all 4 species, assuming Type III survivorship (Caddy \& Sharp 1986) and single exponential mortality. For the regressions, only the right, descending arm of the catch curve is used, as the left arm represents the smallest animals that were not sampled quantitatively. $Z$ is equal to the negative slope of the resulting regression line. Catch curve analysis was done with the computer package FiSAT (Gayanilo et al. 1994).

Reproduction and recruitment. Size at the onset of maturity of females was calculated from the average of 
the 5 smallest ovigerous specimens of each species found over the course of the study. The corresponding age at first maturity for females was estimated using the inverse of the respective VBGF. An estimate for the energy investment per clutch was derived from the ratio of the clutch weight divided by total female weight (both given in $\mathrm{g}$ ash free dry mass). The proportion of egg-carrying females (egg-carrying / total number of mature-sized females) of the 4 fiddler crabs at each sampling date was used as an indicator for reproductive activity and peak breeding periods. Sex ratios were calculated by dividing the total number of female crabs (immature and mature) by the total number of crabs whose sex could be identified at each sampling occasion. Sex ratios were tested against an expected frequency of 1:1 using a chi-squared test (Zar 1999). Averages and standard deviations (SD) were calculated over all sampling dates. The number of recruits (defined as the number of early crab stages) entering the populations between 2 sampling dates was estimated as follows: The maximum size a recruit could reach between any 2 sampling dates was estimated using the VBGF for each of the 4 species. All animals found below this size had consequently recruited during that period. The mortality of recruits between sampling dates was not taken into account and our estimates are therefore conservative.

Abiotic parameters (1 sample taken in each replicate quadrat). Silt/clay content: Sediment samples were taken with a small corer to a depth of $10 \mathrm{~cm}$. Silt/clay content was determined using the method described by Holme \& McIntyre (1984). After drying to constant weight at $100^{\circ} \mathrm{C}$, the sample was weighed, placed in a $63 \mu \mathrm{m}$ sieve, gently broken up after adding hot water and sifted wet until no further sediment could be removed. The remains in the sieve were dried at $100^{\circ} \mathrm{C}$, weighed and silt/clay content calculated.

Water content: Samples were taken with a small corer to a depth of 8 to $10 \mathrm{~cm}$, stored in film containers, weighed wet, dried to constant weight in a freeze drier and weighed again. Water content was then calculated from the difference between wet and dry weight. Samples were always taken at the end of a sampling day at low tide.

Organic content: Samples were scraped from the sediment surface with a spoon and frozen at $-20^{\circ} \mathrm{C}$. In the laboratory, inorganic carbon was removed with $0.02 \mathrm{M} \mathrm{HCl}$, the samples were dried at $100^{\circ} \mathrm{C}$ to constant weight, homogenized and weighed to the nearest $0.1 \mathrm{mg}$.
After burning for $6 \mathrm{~h}$ at $540^{\circ} \mathrm{C}$, the sample was weighed again and organic content was calculated from the weight loss.

Temperature: Air temperature directly above the sediment surface was recorded 2 to 3 times during each sampling day in each replicate (electronic thermometer ama-digit ad 30th, accuracy: $\pm 0.1^{\circ} \mathrm{C}$ ).

Statistical analysis. One-way ANOVA was used to detect differences between environmental parameters in the 3 zones. Heterogeneity of variance was tested with Hartley's F-max test at $\mathrm{p} \leq 0.01$, for unequal sample sizes the approximation suggested in Sokal \& Rohlf (1995) was used. Unplanned mean comparisons were done using Tukey's HSD test (Sokal \& Rohlf 1995). Comparison of environmental parameters in forest quadrats where either Uca vocator or U. rapax dominated were done with independent $t$-tests. $\mathrm{p}$-values are only given for significant differences in the text. Data analysis was done with the statistical package SYSTAT 5.2 for the Macintosh.

\section{RESULTS}

\section{The abiotic environment}

Silt/clay content was significantly higher in F and SC than in LC ( $p<0.001$ in both cases) (Fig. 3). Organic matter content in SC was higher than in the other 2 zones ( $p<0.001$ in both cases), water content in $F$ is lower than in SC and LC ( $p<0.001$ in both cases), and air temperature at the sediment surface was higher in LC compared to F and SC ( $p<0.001$ in both cases).

\section{Crab zonation, abundance and biomass}

Clear differences in the vertical zonation of the 4 fiddler crab species were found between $F(<1 \mathrm{~m}$ below
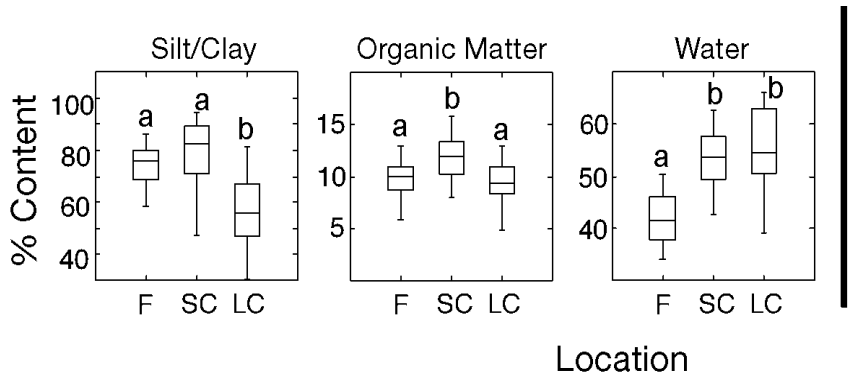

Air Temperature Sediment surface

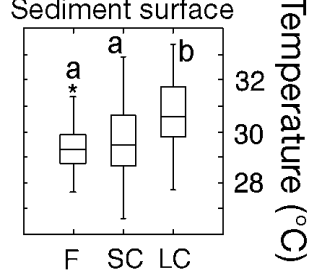

Fig. 3. Box plots of sediment parameters and temperature measured at the sediment surface from the sampling quadrats F (forest), SC (small creek) and LC (large creek). The horizontal line dividing the box is the median, the size of the box denotes the $25 \%$ quartiles (interquartile range), the whiskers delimit \pm 1.5 interquartile ranges from the edges of the box ( $*$ value outside this range). Letters denote homogeneous groups defined by ANOVA and Tukey's HSD post hoc comparison 


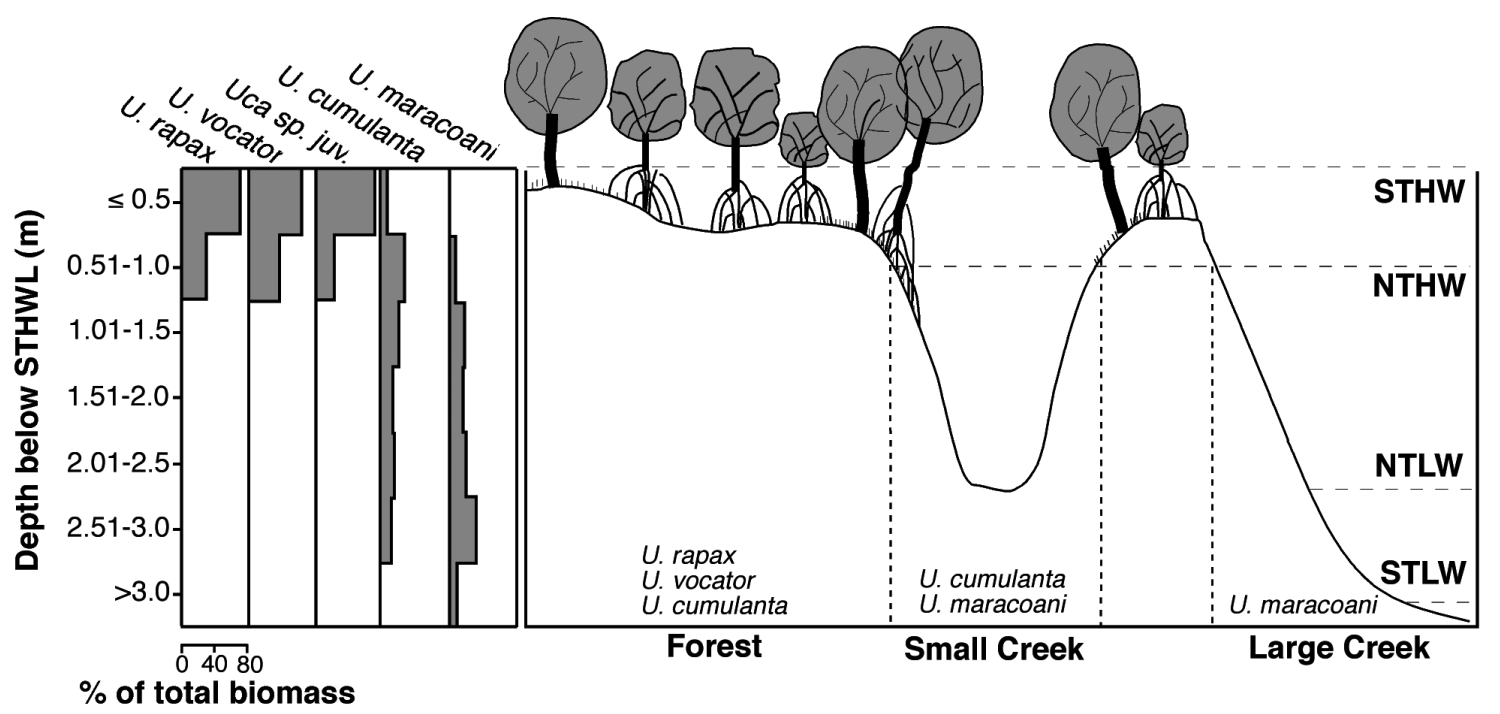

Fig. 4. Vertical zonation of Uca spp. Bar height indicates the percentage of the total biomass of each species found on a certain shore level. The right part of the graph gives a schematic view of the 3 zones sampled, and the dominant species found in each. $\mathrm{ST}=$ spring tide; NT = neap tide; $\mathrm{HW}=$ high water level; $\mathrm{LW}=$ low water level

STHWL), SC (1 to $2.5 \mathrm{~m}$ below STHWL) and LC (1 to $>3 \mathrm{~m}$ below STHWL) (Fig. 4). Uca vocator and U. rapax and their juveniles (Uca sp. juv.) occurred only in $F$, whereas $U$. cumulanta was mostly found in the mid intertidal of $\mathrm{SC}$, but also close to the creek margins in F. U. maracoani occurred at lower tidal levels in SC and was the only species found on the mud banks of LC. None of the species occurred in all 3 zones.

Biomass and abundance of each species in its preferred forest zone varied throughout the sampling period without a clear trend (Table 1). Uca maracoani completely dominated the epifauna in LC and also had the highest biomass in SC. U. cumulanta was by far the most abundant species in SC and contributed over $10 \%$ to the forest biomass ( $>6 \%$ abundance) where $U$.

Table 1. Average biomass (fresh wt, $\mathrm{g} \mathrm{m}^{-2}$ ) and density (no. $\mathrm{m}^{-2}$ ) \pm standard error of Uca spp. in the 3 zones sampled: F (forest), SC (small creek) and LC (large creek). Bold numbers indicate where each species is most abundant. The \% contribution to total epifaunal biomass and abundance in the 3 zones was calculated using values from Koch \& Wolff (2002)

\begin{tabular}{|lcccccc|}
\hline \multirow{2}{*}{ Species } & \multicolumn{2}{c}{ F } & \multicolumn{2}{c}{ SC } & \multicolumn{2}{c|}{ LC } \\
& Biomass & Density & Biomass & Density & Biomass & Density \\
\hline U. cumulanta & $1.1 \pm 1.2$ & $6.7 \pm 6.9$ & $\mathbf{2 . 6} \pm \mathbf{1 . 1}$ & $\mathbf{5 6 . 3} \pm \mathbf{2 2 . 1}$ & - & - \\
U. maracoani & - & - & $6.4 \pm 4.4$ & $12.9 \pm 10.7$ & $\mathbf{7 2 . 9} \pm \mathbf{1 2 . 7}$ & $\mathbf{7 9 . 1} \pm \mathbf{9 . 6}$ \\
U. rapax & $\mathbf{8 . 9} \pm \mathbf{2 . 8}$ & $\mathbf{1 9 . 4} \pm \mathbf{5 . 7}$ & - & - & - & - \\
U. vocator & $\mathbf{9 . 4} \pm \mathbf{2 . 1}$ & $\mathbf{1 8 . 3} \pm \mathbf{8 . 7}$ & - & - & - & - \\
Uca sp. juv. & $\mathbf{0 . 1} \pm \mathbf{0 . 1}$ & $\mathbf{1 4 . 9} \pm \mathbf{1 3 . 9}$ & - & - & - & - \\
$\begin{array}{l}\text { \% of total } \\
\text { epifauna }\end{array}$ & 11.3 & 65.8 & 49.5 & 68.7 & 99.4 & 96.5 \\
\hline
\end{tabular}

vocator and U. rapax were dominant. Highest biomass values were found in LC, followed by F and SC. Abundance was also highest in LC, followed by SC and F. The 4 fiddler crab species made up a large part of total epifaunal abundance (65.8 to $96.5 \%$ ) and biomass (11.3 to $99.4 \%$ ) in the 3 zones (data in last row of Table 1 taken from Koch \& Wolff 2002). The low \% contribution in F resulted from the dominance of another ocypodid crab, the leaf-eating Ucides cordatus.

To test if and how the distribution of Uca rapax and $U$. vocator in the forest was related to temperature, grain size, organic matter and water content, the dominance of each species was used as a grouping variable for the environmental parameters measured. Only those sampling quadrats were used where either of the 2 species accounted for at least $75 \%$ of their combined biomass ( $U$. vocator: $\mathrm{n}=14 ; U$. rapax: $\mathrm{n}=11)$. U. vocator was dominant in areas with higher organic (independent $t$-test: $\mathrm{p}=0.014)$ and water content $(\mathrm{p}=0.027)$ when compared to areas were $U$. rapax was dominant. Although U. vocator was generally found in sediments with higher silt/clay content, the differences were not significant $(p=0.086)$. No preferences were found regarding the air temperature at the sediment surface $(p=0.477)$. 


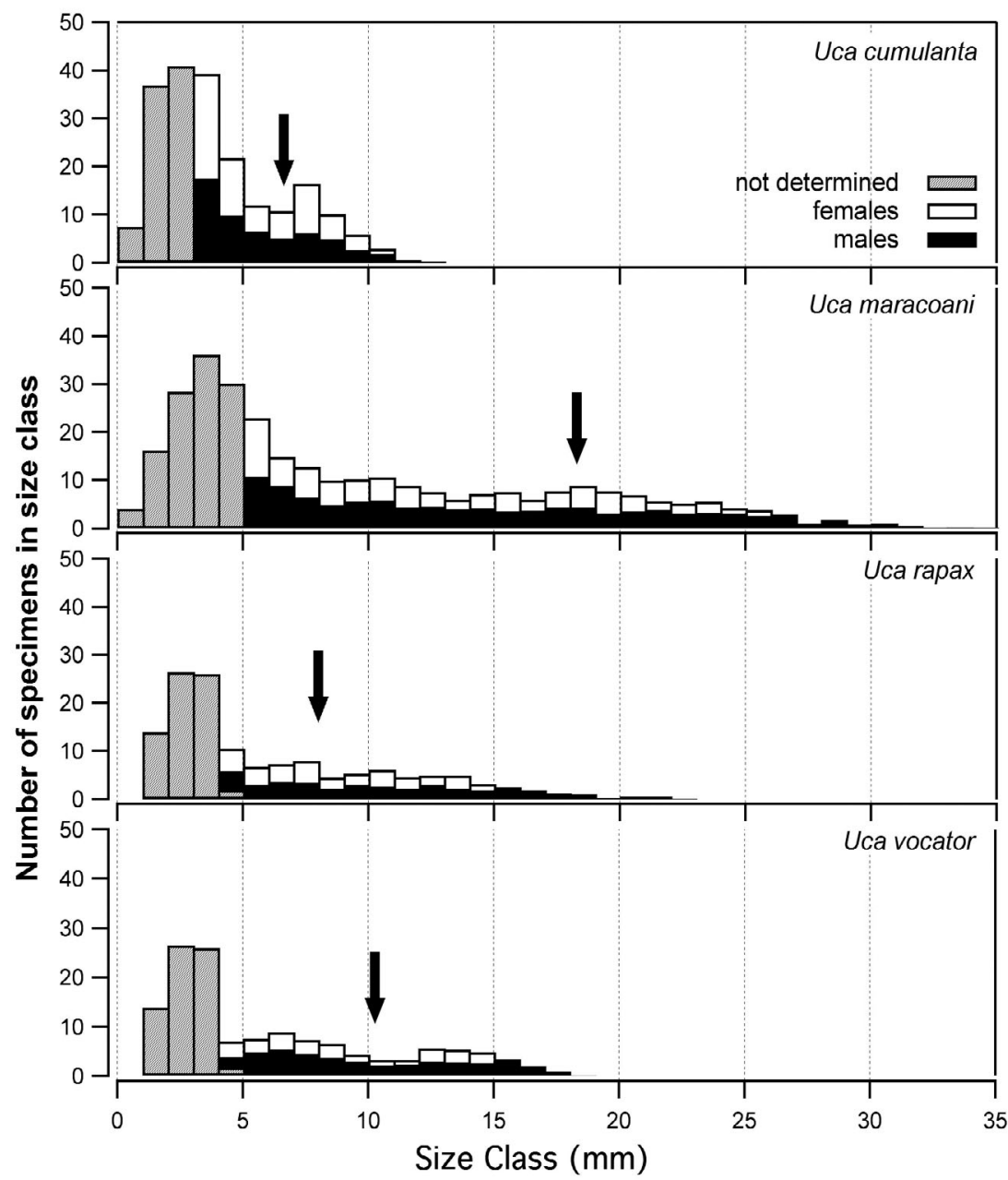

Fig. 5. Population size structure of Uca spp. As juveniles of U. rapax and $U$. vocator could not be distinguished, the total amount of $U_{c a} \mathrm{sp}$. juv. is shown in the graphs for the species. Black arrows give the size at maturity for females, estimated as the average of the 5 smallest egg-carrying females in the sample. Numbers in each size class represent the average number of specimens found per sampling occasion $\left(3.92 \mathrm{~m}^{2}\right)$

\section{Growth}

Growth measurements in the cage experiments included almost the whole size range $>6 \mathrm{~mm}$ for all species. SD was generally small and never exceeded $15 \%$ of the average value (Fig. 6). This ensured a good coverage of most of the calculated growth curve with actual measurements. The growth parameters calculated with the Munro-plot (Table 2) show a good fit, with the standard error of $K$ being around 10\% of the mean. Munro's $\phi^{\prime}$ was highest in Uca maracoani and lowest in $U$. cumulanta. Variation between sexes was small, except for $U$. cumulanta, where $\phi^{\prime}$ of females was $15 \%$ lower than that of males.

\section{Mortality}

The total mortality rates $(Z)$ as calculated from the length-converted catch curves (Fig. 7) were highest in Uca cumulanta, followed by $U$. vocator, U. maracoani and $U$. rapax. Generally, females had about $20 \%$ higher mortality rates than males, except for $U$. cumulanta, where the value of males was approx. $10 \%$ higher. The mortality estimate for $U$. vocator had wide confidence intervals and the graph indicates that this species might not quite follow the single exponential mortality. However, the $Z$-value resulting from the single exponential model was used as an estimate to be able to compare mortality rates among species.

\section{Population size structure}

The size frequencies of each species during the sampling period (Fig. 5) show a strong peak at the smallest size classes in all 4 species. A second, and much smaller, peak was present in Uca cumulanta, U. maracoani and also in $U$. vocator that coincides closely with the size at which females first reach sexual maturity (arrows in Fig. 5). Sex ratios were significantly different from 1:1 only in $U$. cumulanta and $U$. rapax, with females being more abundant in both cases (see Table 3).
Table 2. Parameters of the von Bertalanffy growth function $\left(L_{\infty}, K \pm \mathrm{SE}\right)$ for males and females of Uca spp. as calculated with the Munro plot. Size range over which growth was measured is shown. Maximum age is defined as the age where $95 \%$ of $L_{\infty}$ is reached; $\phi^{\prime}$ is Munro's growth performance index

\begin{tabular}{|lllcccc|}
\hline Species & Sex & $\begin{array}{c}\text { Size range } \\
\text { used }(\mathrm{mm})\end{array}$ & $\begin{array}{c}L_{\infty} \\
(\mathrm{mm})\end{array}$ & $\begin{array}{c}K \pm \mathrm{SE} \\
\left(\mathrm{yr}^{-1}\right)\end{array}$ & $\begin{array}{c}\text { Max. age } \\
(\mathrm{yr})\end{array}$ & $\phi^{\prime}$ \\
\hline U. cumulanta & Males & $6.0-12.5$ & 13.1 & $4.22 \pm 0.14$ & 0.71 & 2.0 \\
& Females & $6.0-10.9$ & 11.1 & $4.24 \pm 0.49$ & 0.70 & 1.7 \\
U. maracoani & Males & $7.0-24.6$ & 35.2 & $2.03 \pm 0.14$ & 1.47 & 3.2 \\
& Females & $7.0-25.3$ & 31.0 & $2.44 \pm 0.29$ & 1.23 & 3.0 \\
U. rapax & Males & $6.9-18.0$ & 20.5 & $2.08 \pm 0.22$ & 1.44 & 2.2 \\
& females & $7.1-18.0$ & 20.0 & $2.15 \pm 0.28$ & 1.40 & 2.2 \\
U. vocator & Males & $6.6-20.0$ & 21.6 & $2.71 \pm 0.27$ & 1.10 & 2.5 \\
& Females & $6.5-19.3$ & 20.6 & $2.97 \pm 0.28$ & 1.01 & 2.5 \\
\hline
\end{tabular}




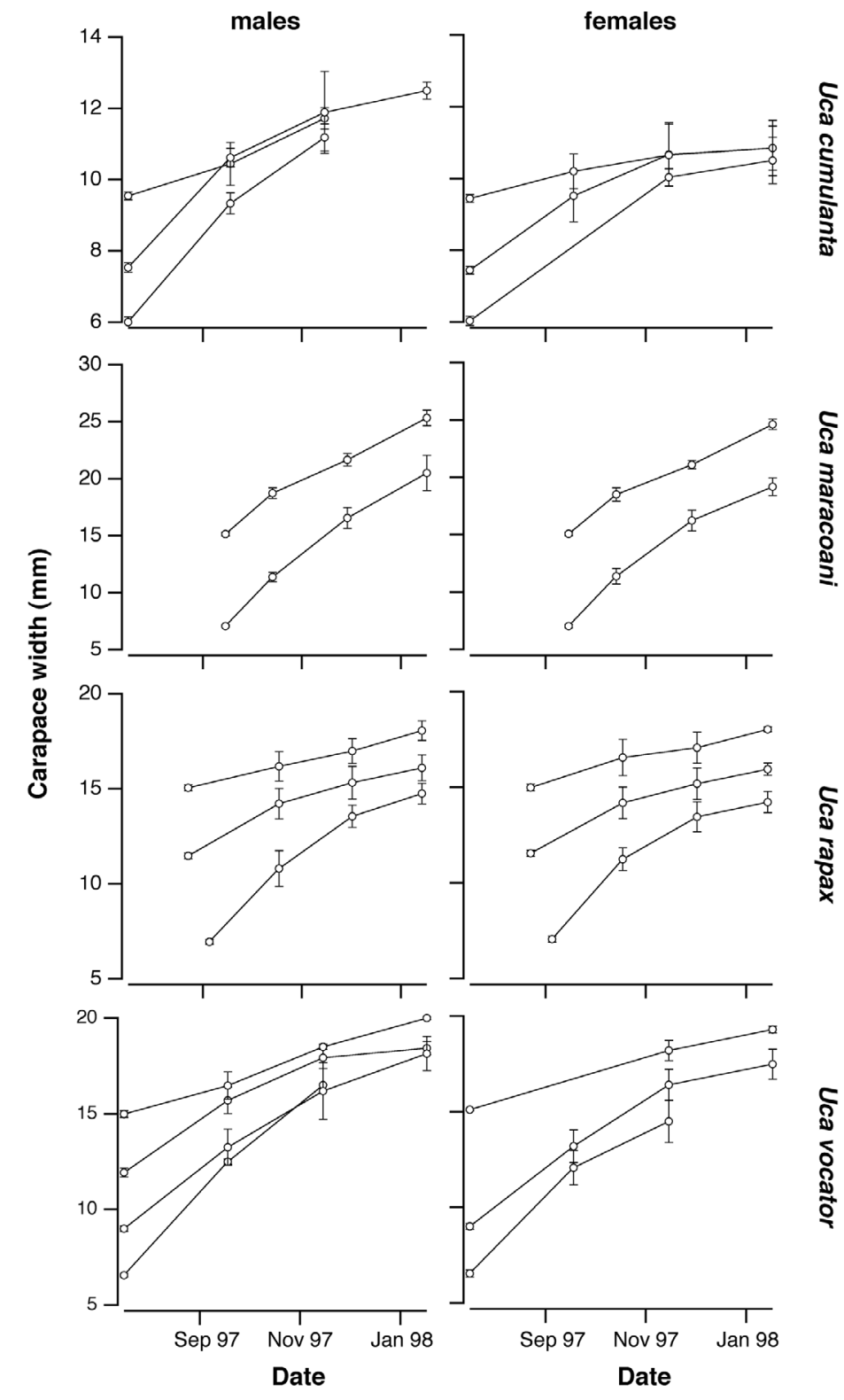

Fig. 6. Growth increments of Uca spp. obtained from the cage experiments. Average $\mathrm{CW} \pm \mathrm{SD}$ are given for males and females separately. Each line corresponds to the specimens in 1 cage compartment ('artificial cohort'). Note that the $y$ axes have different scales

\section{Reproduction and recruitment}

The proportion of egg-carrying females and the number of juveniles recruited between any 2 sampling dates is shown in Fig. 8, together with salinity and precipitation values for the study period. Most precipitation occurred between January and June and salinity was below 15 PSU during this time (in 1998, values almost approached 0 PSU during times of heavy rainfall). Ovigerous Uca maracoani females were mostly found in the drier season, when recruitment was highest (up to 50 recruits $\mathrm{m}^{-2}$ in $6 \mathrm{wk}$ ). However, fairly high levels of recruitment occurred also during the wet season when none or few egg-carrying females were found. Reproductive activity of $U$. cumulanta also seemed to be more concentrated during the drier season, when the proportion of egg-carrying females peaked at 0.3 to 0.4 from September 1997 to January 1998. Peak recruitment however, was found at the end of the rainy season in June with about 60 recruits $\mathrm{m}^{-2}$ in $7 \mathrm{wk}$. Egg-carrying females of $U$. rapax were found throughout the study period with a small peak from October to December at the end of the dry season. U. vocator, on the other hand, had a very pronounced reproductive peak from March to June. Generally, recruitment levels of UCa sp. juv. were highest at the end of the rainy and beginning of the dry season from May to September (up to 50 recruits $\mathrm{m}^{-2}$ per $6 \mathrm{wk}$ ), and were lower during the rest of the year (10 to 15 recruits $\mathrm{m}^{-2}$ per $6 \mathrm{wk}$ )

The age at onset of maturity was very similar ( 0.20 to $0.23 \mathrm{yr}$ ) in all species except for the largest species, Uca maracoani, with 0.36 yr (Table 3 ). Size at onset of maturity was around or a little over half the maximum size $\left(L_{\infty}\right)$ in all species except for $U$. rapax where females reached reproductive size at just over $1 / 3$ of their maximum size. Energy investment per clutch was similar in all species (not measured in U. rapax) with 11 to $13 \%$ of the ash-free dry mass of the organism.

\section{DISCUSSION}

\section{Crab zonation, abundance and biomass}

Zonation of the 4 fiddler crab species was characterized by Uca rapax and $U$. vocator being restricted to the high intertidal forest, while $U$. cumulanta and $U$. maracoani were found in the mid and low intertidal. The distribution limit between the 2 groups coincided well with the neap high tide level (NHTL) and the observed zonation is consistent with the findings of Crane (1975).

The spatial distribution of the 4 fiddler crab species was strongly related to sediment characteristics and correlated with the number, size and form of setae on their feeding appendages. Species possessing abundant spoon-tipped setae (sturdy setae with little spoonshaped tips) on their second maxillipeds are best adapted to feeding on sandy sediments with low organic content, while species feeding on muddy sediments with high organic content primarily have plumose setae (more flexible, featherlike setae) (Altevogt 1957, Miller 1961, Crane 1975, Icely \& Jones 1978, Robertson \& Newell 1982b). Microscopical examination showed that the number of spoon-tipped 

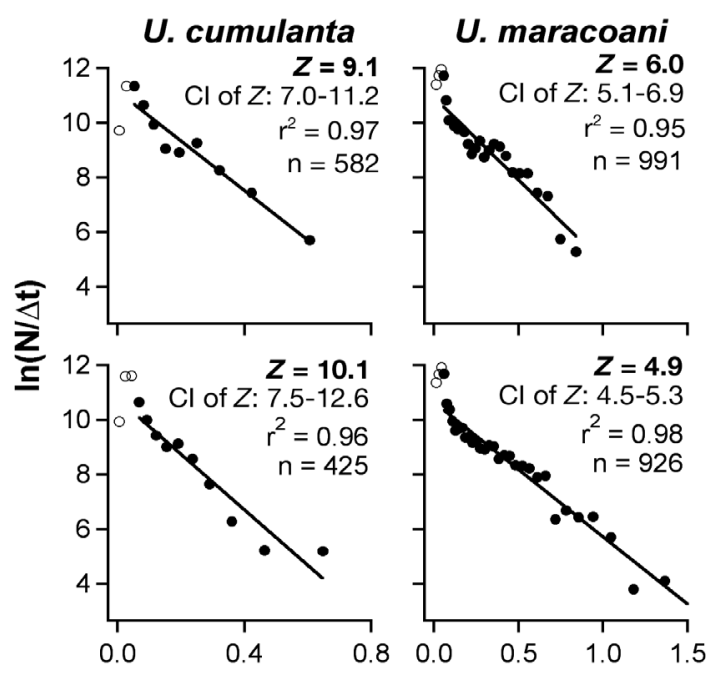

Age (years)
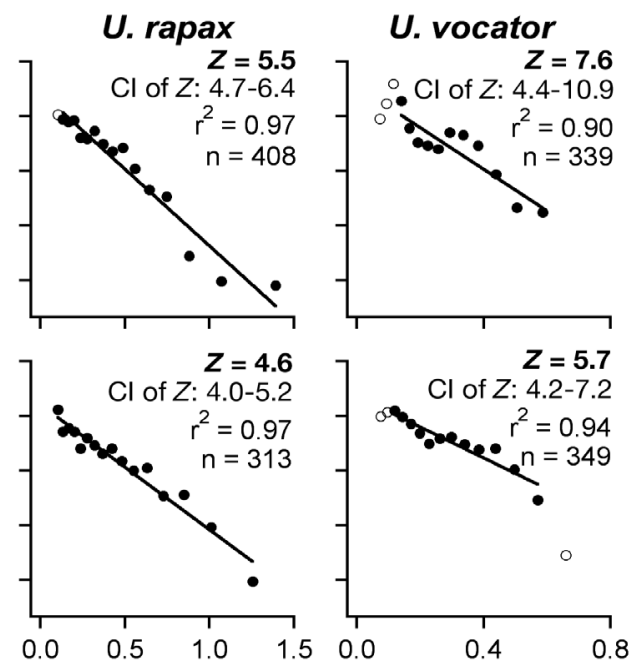

$Z=7.6$

$\therefore$ Cl of $Z: 4.4-10.9$

\section{U. vocator}

$r^{2}=0.90$
$n=339$

D

Fig. 7. Length-converted catch curves for males and females of UCa spp. Total $Z$ with confidence intervals (CI) and goodness of fit $\left(\mathrm{r}^{2}\right)$ of the regression are given in each graph. Only data points represented by filled circles $(\bullet)$ were used to calculate the regression line setae was highest in UCa maracoani, followed by $U$. rapax and $U$. cumulanta, while $U$. vocator possessed only plumose setae (Koch 1999). Accordingly, in the mid and low intertidal $U$. maracoani was found in areas with high sand and low organic content while $U$. cumulanta was most abundant in SC, the zone with the highest silt/clay and organic content.

In F, Uca vocator was dominant in sediments with higher organic content, while $U$. rapax was most abundant in areas with low organic content as predicted by the setae types found. No direct dependence on sediment grain size was found ( $t$-test, $p=0.086)$, but silt/clay content in the area had a comparably narrow range (55 to $85 \%$ ). The distribution of $U$. rapax and $U$. vocator in the upper part of the forest could also have been influenced by differing tolerance against desiccation: while the former predominated in dry and sunny areas (Wessels 1999, V. Koch pers. obs.), the latter was found to prefer shaded areas with higher water content of the sediment. However, no experiments were done to test for desiccation tolerance of the 2 species.
In LC, temperature tolerance appears as a major factor influencing species distribution. Temperatures on the sunny creek banks often exceeded 35 to $38^{\circ} \mathrm{C}$ while they remained 3 to $5^{\circ} \mathrm{C}$ lower in the other zones where tree cover provided shade. Uca maracoani seems best adapted to cope with these conditions. Oxygen consumption measured in water at different temperatures by Koch (1999) revealed that $\mathrm{O}_{2}$ consumption of $U$. maracoani increased up to a temperature of $35^{\circ} \mathrm{C}$, while all other species showed highly reduced $\mathrm{O}_{2}$-consumption at temperatures above 30 to $32^{\circ} \mathrm{C}$, indicating physiological stress due to overheating. If crabs have to retreat to their burrows to avoid heat stress, foraging time would be reduced, putting them at a disadvantage.

Biomass and abundance values for the 4 species were within the range reported for fiddler crabs (e.g. Teal 1958, 1962, Warner 1969, Wolf et al. 1975, Cammen et al. 1980, Colby \& Fonseca 1984, Jones 1984). While abundance was rather similar, marked differences in biomass were found between zones. Highest

Table 3. Reproductive parameters of female Uca spp. (average \pm SD). Age and size at first maturity was calculated as the average of the 5 smallest egg-carrying females of each species. p-values for the chi-squared test are given in parentheses below the proportion of females in each species

\begin{tabular}{|c|c|c|c|c|c|}
\hline Species & $\begin{array}{l}\text { Age at first } \\
\text { maturity (yr) }\end{array}$ & $\begin{array}{l}\text { Size at first } \\
\text { maturity }(\mathrm{mm})\end{array}$ & $\begin{array}{l}\text { Clutch weight in \% of } \\
\text { female ash-free dry mass }\end{array}$ & $\begin{array}{l}\% \text { females in population } \\
\left(p, \chi^{2} \text { test }\right)\end{array}$ & $\begin{array}{c}\text { Reproductive season } \\
\text { (peak mo) }\end{array}$ \\
\hline U. cumulanta & $0.20 \pm 0.01$ & $6.2 \pm 0.1$ & $\begin{array}{c}10.9 \pm 4.6 \\
(\mathrm{n}=23)\end{array}$ & $\begin{array}{l}58.6 \pm 5.9 \\
(p<0.001)\end{array}$ & Sep-Jan \\
\hline U. maracoani & $0.36 \pm 0.01$ & $18.0 \pm 0.3$ & $\begin{array}{l}11.2 \pm 1.3 \\
(\mathrm{n}=5)\end{array}$ & $\begin{array}{l}49.5 \pm 5.8 \\
(p>0.05)\end{array}$ & Jun-Nov \\
\hline U. rapax & $0.22 \pm 0.01$ & $7.4 \pm 0.2$ & - & $\begin{array}{l}56.3 \pm 3.3 \\
(p<0.001)\end{array}$ & Oct-Dec \\
\hline U. vocator & $0.23 \pm 0.03$ & $9.9 \pm 1.0$ & $\begin{array}{l}12.9 \pm 2.5 \\
(\mathrm{n}=5)\end{array}$ & $\begin{array}{l}48.1 \pm 10.2 \\
(p>0.05)\end{array}$ & Mar-Jun \\
\hline
\end{tabular}




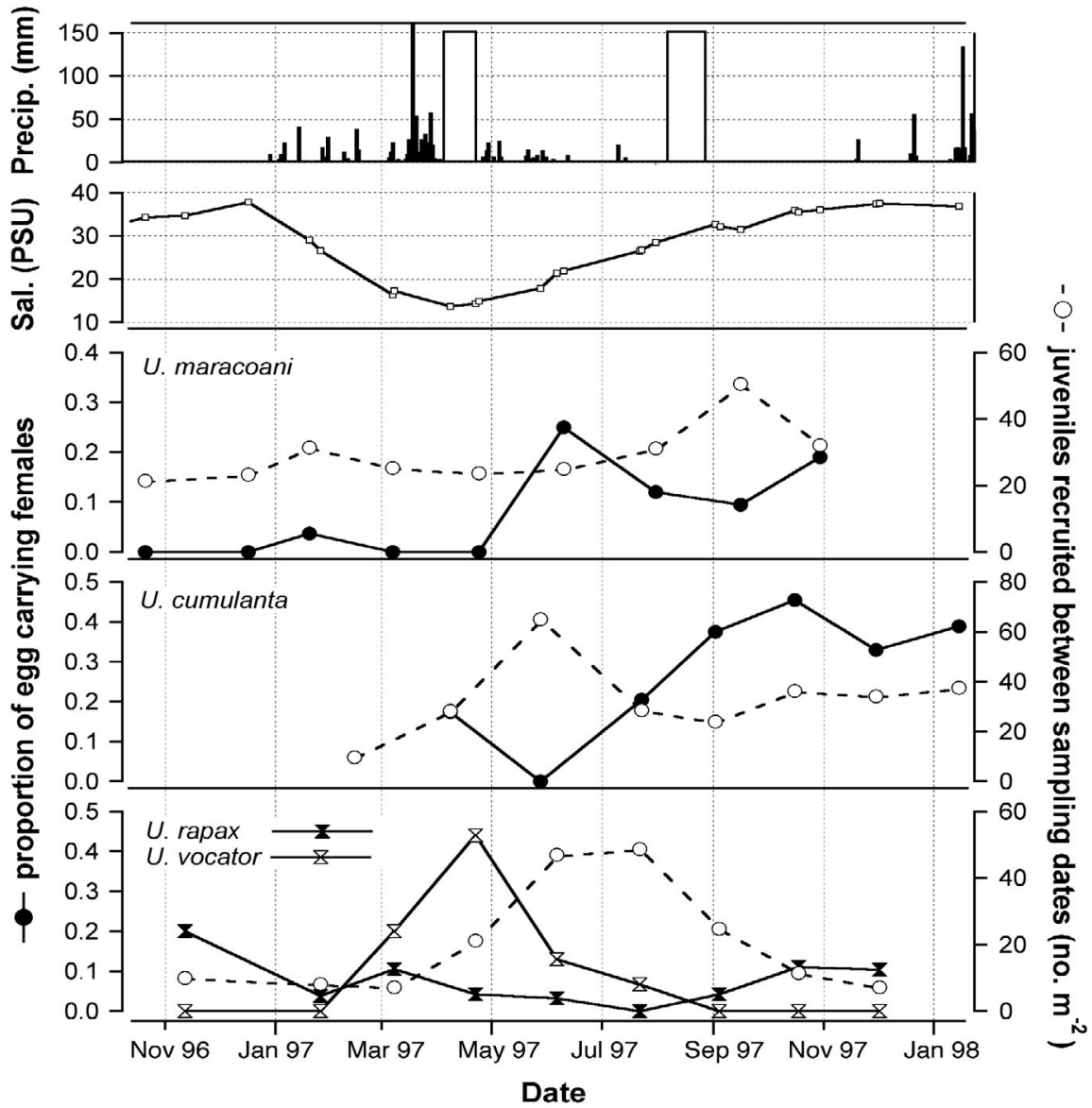

Fig. 8. Proportion of egg-carrying females $(\bullet$, except for Uca rapax and $U$. vocator, which are represented by filled and open double triangles, respectively) and number of recruits of each fiddler crab species (O) throughout the study period. Precipitation and salinity fluctuations over the same time period are given in the upper 2 graphs for comparison. White bars in the precipitation graph indicate periods where no rainfall data were available values were found in LC dominated by Uca maracoani, where secondary production was also found to be highest by Koch \& Wolff (2002), possibly because food production by bacteria and microalgae exceeded that of the other zones. The 4 fiddler crabs accounted together for about $11.2 \%$ of the total faunal biomass in the Caeté mangrove ecosystem (Wolff et al. 2000), but for almost $90 \%$ of total epibenthic production (Koch \& Wolff 2002), indicating fast growth and turnover rates.

\section{Population structure, growth and mortality}

The population structure of all 4 species is typical for fast-growing, short-lived species where juveniles dominate the population (Hartnoll 1982, Hartnoll \& Bryant 1990). Uca rapax had the highest proportion of adult-sized individuals (40.9\%), followed by U. vocator $(28.8 \%), U$. cumulanta $(26.5 \%)$ and $U$. maracoani $(16.6 \%)$. No clear cohorts were visible in any of the size frequency histograms, although small, secondary peaks are present. However, as fiddler crabs in general (with the possible exception of $U$. vocator, see below) have rather prolonged breeding seasons, no attempt was made to relate these secondary peaks to different cohorts. Sex ratios of $U$. maracoani and $U$. vocator were close to 1, corresponding to Fisher's theory (Fisher 1930). The significantly higher proportion of females in $U$. cumulanta and $U$. rapax contradict several studies on fiddler crabs that reported much higher proportions of males as a rule (for a review, see Montague 1980). Considering, however, that the mating system of $U c a$ spp. is promiscuous with territorial males competing for females, deviations from Fisher's 1:1 ratio should favor females (Willson \& Pianka 1963, Emlen 1973), as found in our study. It remains unclear however, how this fits in with the higher mortality rates measured in females of all species except $U$. cumulanta (see below).

Growth of all fiddler crabs examined was fast and the calculated maximum life spans short $(0.7$ to $1.47 \mathrm{yr}$ ). Individual growth rates varied little as indicated by the small SD within the 'artificial cohorts'. Temperate fiddler crabs grow slower and have longer maximum life spans (up to 4 yr) but their growing season lasts only 7 to 9 mo and the crabs spend the coldest months hibernating in their burrows (Shanholtzer 1973, Montague 1980, Colby \& Fonseca 1984). The geographical distribution of the genus Uca at higher latitudes is mainly limited by low temperatures and length of growing season (Crane 1975); longer life 
spans and slower growth rates can thus be expected towards the distribution limits.

Growth rates of males and females were quite similar in all 4 species, as is reported by Shanholtzer (1973) for Uca pugnax. Higher K-values of female fiddler crabs were compensated for by larger $L_{\infty}$ values of males, and growth performance indices for both sexes are similar. Only in $U$. cumulanta was growth performance about $17 \%$ higher in males. Possibly, females of this species invest comparably more in reproduction than the other species, or males have lower energy investments in territory defense and courtship behavior, a time- and energy-consuming activity for male fiddler crabs (Crane 1975). Growth performance was highest in $U$. maracoani and lowest in $U$. cumulanta. Values for $U$. rapax and $U$. vocator, the 2 species cooccurring in $\mathrm{F}$, differed considerably, with the latter having $>20 \%$ higher values. Niche separation of these 2 fiddler crabs could therefore partly be achieved by their different growth strategies.

The use of cages built in the natural environment was considered the best possible choice to measure growth as individual crabs were too small to be tagged reliably without risking damage and reducing growth and survivorship (Cobb \& Caddy 1989). Effects of the experimental setup on growth rates were minimized by ensuring that (1) density and biomass in the cages were within the range encountered in the field; (2) cages were built only in areas were crabs were observed to live and feed; (3) sediment disturbance was kept minimal during sampling. Also, measurements of sediment organic content showed similar values inside and outside the cages. However, possible bias (and reduction of growth rates) introduced by differing foraging area size of each species was not tested for, and the growth estimates presented here are probably conservative.

Mortality rates $(Z)$ were high for all species (4.6 and $7.6 \mathrm{yr}^{-1}$ ), with the highest values found in male and female Uca cumulanta (9.1 and $10.6 \mathrm{yr}^{-1}$, respectively). This is consistent with their much smaller size and faster growth rate compared to the other species. Turnover rates of temperate fiddler crabs from the southern United States were much lower (2.2 to $3.3 \mathrm{yr}^{-1}$ ) than those found in the present study (Teal 1962, Cammen et al. 1980). Alongi (1989) attributed this pattern to a lack of temperature compensation in metabolic processes and to higher predation pressure in the tropics. Except for $U$. cumulanta, mortality rates of males were consistently 10 to $20 \%$ lower, which can be expected as male fiddlers can shed their large claw when attacked and have a higher chance to escape a predator (Wolf et al. 1975, Lee \& Kneib 1994). Predation is the most important source of mortality in fiddler crabs in the Caeté estuary (Wolff et al. 2000, Koch \& Wolff 2002) and the crabs make up a substantial part of the diet of many birds, fish, predatory crabs and mammals (Montague 1980, Montague et al. 1981, Jones 1984, Wiedemeyer 1997, Keuthen 1998, Wolff et al. 2000). The mortality rates found in this study were close to those found in many shrimp populations (3 to $11 \mathrm{yr}^{-1}$ ) (e.g. Devi 1987, Caddy 1989, Gracia 1989, D'Incao 1990, Jayawickrema \& Jayakody 1992, Gabche \& Hockey 1995, Xu et al. 1995) that are also fast-growing, highly productive and feed partly on detritus. From a functional point of view, both groups are similar and occupy important positions in the food webs of their respective environments (Caddy \& Sharp 1986, Caddy 1989, Wolff et al. 1998, Wolff et al. 2000).

\section{Reproduction and recruitment}

Females of all species (except Uca rapax, not measured) invested similar amounts of energy in each clutch (11 to $13 \%)$, but it remains unclear whether the species differ in total reproductive investment as the number of clutches over a female's life span was not determined. All fiddler crabs showed prolonged breeding seasons, as can be expected for tropical species (Ahmed 1976, Sastry 1983). While U. cumulanta and $U$. maracoani bred mostly during the drier season (June to December), U. rapax seemed to breed almost year-round with only a small peak between October and December (see also Ahmed 1976). Reproduction in $U$. vocator, however, showed a pronounced peak during the end of the rainy season. The differences in reproductive timing of the 2 forest species can provide a temporal niche separation as has been suggested for sympatric portunid swimming crabs with broad dietary and habitat overlap (Paul 1982, Negreiros-Franzoso \& Franzoso 1995, Pinheiro et al. 1997).

Peak recruitment was remarkably constant for all species, with 50 to 60 recruits $\mathrm{m}^{-2}$ in 6 wk. True numbers of recruits must have been higher as mortality was not considered in the calculations. The number of juvenile crabs recruiting to the study area did not coincide well with the occurrence of egg-carrying females found on the previous sampling date. Recruits were found even when no ovigerous females had been recorded previously. Low sampling efficiencies of eggcarrying females can be excluded, as high proportions of ovigerous females were found on other occasions and the removal efficiency of the sampling technique was $88 \%$ in LC and $>95 \%$ in F and SC (Koch \& Wolff 2002). However, recruits could have originated from other locations, as larvae of many Uca sp. are exported from estuaries and can be dispersed over considerable distances (e.g. Christy \& Stancyk 1982, Epifanio et al. 1988, Rodriguez et al. 1997, Drake et al. 1998). Diele (2000) showed that occurrence of ovigerous females of 
the ocypodid crab Ucides cordatus varied widely among different locations in the Caeté estuary. Therefore, the sampled area might have been too small to adequately describe reproductive activities of the fiddler crab populations for the whole study area.

In conclusion, the overall theme of fiddler crab life history strategy appears to be: 'live fast, die young, and reproduce early'. In comparison to their temperate relatives, growth and mortality rates were higher, as can be expected. The high population turnover and productivity explains why fiddler crabs occupy a key position in the intertidal food web, where they efficiently convert microbial production into energy available to higher trophic levels (e.g. Teal 1962, Montague 1980, Koch \& Wolff 2002).

Acknowledgements. Many thanks to our Brazilian and German colleagues of the MADAM project, without whom this study would not have been possible. Special thanks to S. Knieriem, O. Gunderman and U. Mehlig. This study was part of the MADAM project, a Brazilian-German cooperation financed by the Brazilian National Research Council (CNPq) and the German Ministry for Education and Research (BMBF) under the code 03F0154A. This is MADAM-Contribution No. 84.

\section{LITERATURE CITED}

Adiyodi RG (1989) Reproduction and development. In: Burgren WW, McMahon BR (eds) Biology of the land crabs. Cambridge University Press, Cambridge, p 139-185

Ahmed M (1976) A study of the normal and aberrant sexual types of the Venezuelan fiddler crabs Uca cumulanta and Uca rapax. Bull Mar Sci 26:499-505

Alongi DM (1989) Ecology of tropical soft-bottom benthos: a review with emphasis on emerging concepts. Rev Biol Trop 37(1):85-100

Altevogt R (1957) Untersuchungen zur Biologie, Ökologie und Physiologie indischer Winkerkrabben. Z Morph Ökol Tiere 46:1-110

Begon M, Harper JL, Townsend CR (1996) Ecology, 3rd edn. Blackwell Science, Oxford

Bradley PM, Morris JT (1990) Influence of oxygen and sulfide concentrations on nitrogen uptake kinetics in Spartina alterniflora. Ecology 71:282-287

Caddy JF (ed) (1989) Marine invertebrate fisheries: their assessment and management. John Wiley \& Sons, New York

Caddy JF, Sharp GD (1986) An ecological framework for marine fisheries investigations. FAO Fish Tech Pap 283

Cammen LM, Seneca ED, Stroud LM (1980) Energy flow through the fiddler crabs Uca pugnax and Uca minax and the marsh periwinkle Littorina irrorata in a North Carolina salt marsh. Am Midl Nat 103(2):238-250

Christy J, Stancyk SE (1982) Timing of larval production and flux of invertebrate larvae in a well mixed estuary. In: Kennedy V (ed) Estuarine comparisons. Academic Press, New York, p 489-503

Cobb JS, Caddy JF (1989) The population biology of decapods. In: Caddy JF (ed) Marine invertebrate fisheries: their assessment and management. John Wiley \& Sons, New York, p 327-374

Colby DR, Fonseca MS (1984) Population dynamics, spatial dispersion and somatic growth of the sand fiddler crab Uca pugilator. Mar Ecol Prog Ser 16:269-279

Crane J (1975) Fiddler crabs of the world. Ocypodidae: Genus
Uca. Princeton University Press, Princeton, NJ

Devi SL (1987) Growth and population dynamics of three penaeid prawns in the trawling grounds off Kakinada. Indian J Fish 34(3):245-264

Diele K (2000) Life history and population structure of the exploited mangrove crab Ucides cordatus cordatus (Linnaeus, 1763) (Decapoda: Brachyura) in the Caeté Estuary, North Brazil. PhD thesis, University of Bremen

D'Incao F (1990) Mortalidade de Penaeus (Farfantepenaeus) paulensis Perez-Farfante 1967 no estuario do Lagoa dos Patos, Rio Grande do Sul, Brasil (Crustacea, Penaeidae). Atlantica 12(2):31-51

Drake P, Arias AM, Rodriguez A (1998) Seasonal and tidal abundance patterns of decapod crustacean larvae in a shallow inlet (SW Spain). J Plankton Res 20(3):585-601

Dye AH, Lasiak TA (1986) Microbenthos, meiobenthos and fiddler crabs: trophic interactions in a tropical mangrove sediment. Mar Ecol Prog Ser 32:259-264

Dye AH, Lasiak TA (1987) Assimilation efficiencies of fiddler crabs and deposit-feeding gastropods from tropical mangrove sediment. Comp Biochem Physiol 87A(2):341-344

Emlen JM (1973) Ecology: an evolutionary approach. AddisonWesley, Reading, MA

Epifanio CE, Little KT, Rowe PM (1988) Dispersal and recruitment of fiddler crab larvae in the Delaware River Estuary. Mar Ecol Prog Ser: 43:181-188

Fisher RA (1930) The genetical theory of natural selection. Clarendon Press, Oxford

Frith DW, Brunnenmeister S (1980) Ecological and population studies of fiddler crabs (Ocypodidae, genus Uca) on a mangrove shore at Phuket Island, western peninsula Thailand. Crustaceana 39:157-184

Frusher SD, Giddins RL, Smith III TJ (1994) Distribution and abundance of grapsid crabs in a mangrove estuary: effects of sediment characteristics, salinity tolerances and osmoregulatory ability. Estuaries 17(3):647-654

Gabche C, Hockey HUP (1995) Growth and mortality of the giant African river prawn Macrobrachium voellenhovenii (Herklots: Crustacea, Palaemonidae) in Tie Lobe River, Cameroon: A preliminary evaluation. J Shellfish Res 14(1): 185-190

Gayanilo FC Jr, Sparre P, Pauly D (1994) The FAO-ICLARM Stock Assessment Tools (FiSAT) user's guide. FAO Computerized Information Series. Fisheries, Food and Agriculture Organization of the United Nations, Rome

Genoni GP (1985) Food limitation in salt marsh fiddler crabs Uca rapax (Smith) (Decapoda: Ocypodidae). J Exp Mar Biol Ecol 87:97-110

Gerlach SA (1958) Die Mangrovenregion tropischer Küsten als Lebensraum. Z Morph Ökol Tiere 46:636-730

Gracia GA (1989) Mortalidad natural del camarón blanco Penaeus setiferus (Linnaeus 1767) en la sonda de Campeche. An Inst Cienc Mar Limnol Univ Nac Auton Mexico 16(2):263-272

Hartnoll RG (1982) Growth. In: Abele LG (ed) The biology of crustacea, vol 2. Academic Press, New York, p 11-196

Hartnoll RG, Bryant AD (1990) Size-frequency distributions in decapod crustacea - the quick, the dead, and the cast-offs. J Crustac Biol 10(1):14-19

Holme NA, McIntyre AD (1984) Methods for the study of marine benthos. IBP Handbook no.16. Blackwell Scientific Publications, Oxford

Icely JD, Jones DA (1978) Factors affecting the distribution of the genus Uca (Crustacea: Ocypodidae) on an East African shore. Estuar Coast Shelf Sci 6(3):315-325

INMET (Institut Nacional de Metereologia) (1992) Normais climatológicas (1961-1990). Tech Rep Instituto Nacional de Metereologia, Brasilia DF 
Jaramillo E, Lunecke K (1988) The role of sediments in the distribution of Uca pugilator and Uca pugnax in a salt marsh of Cape Cod. Meeresforsch 32:46-52

Jayawickrema S, Jayakody DS (1992) Population dynamics of Penaeus indicus (H. Milne Edwards) in the west coast of Sri Lanka. J Mar Biol Assoc India 34(1-2):94-102

Jones D (1984) Crabs of the mangal ecosystem. In: Por F, Dor I (eds) Hydrobiology of the mangal. Junk Publishers, The Hague, p 89-109

Keuthen H (1998) Nahrungsökologische Untersuchungen an ausgewählten Beispielen der Ichthyofauna der Mangrove vor Bragança (Pará, Brasilien). Master's thesis, University of Hamburg

Koch V (1999) Epibenthic production and energy flow in the Caeté Mangrove Estuary, North Brazil. PhD thesis, University of Bremen

Koch V, Wolff M (2002) Energy budget and ecological role of mangrove epibenthos in the Caeté estuary, North Brazil. Mar Ecol Prog Ser 228:119-130

Lee SY, Kneib RT (1994) Effects of biogenic structure on prey consumption by the xanthid crabs Eurytium limosum and Panopeus herbstii in a salt-marsh. Mar Ecol Prog Ser 104: $39-47$

Macintosh DJ (1984) Ecology and productivity of Malaysian mangrove crab populations (Decapoda: Brachyura). In: Ong JE, Gong WK (eds) Proceedings of the workshop on productivity of the Mangrove ecosystem: management implications. University Sains Malaysia, Penang, p 354-377

Macintosh DJ (1988) The ecology and physiology of decapods of mangrove swamps. In: Fincham A Rainbow PS (eds) Aspects of decapod crustacean biology. Symp Zool Soc Lond 59:315-341

Macnae W (1968) A general account of the fauna and flora of mangrove swamps and forests in the Indo-West-Pacific region. Adv Mar Biol 6:73-170

Mehlig U (2001) Aspects of tree primary production in an equatorial mangrove forest in Brazil. PhD dissertation, University of Bremen

Miller DC (1961) The feeding mechanisms of fiddler crabs, with ecological considerations of feeding adaptations. Zool 46(8):89-101

Montague CL (1980) A natural history of temperate Western Atlantic fiddler crabs (genus $U_{C a}$ ) with reference to their impact on the salt marsh. Contr Mar Sci 23:25-55

Montague CL, Bunker SM, Haines EB, Pace ML, Wetzel RL (1981) Aquatic macroconsumers. In: Pomeroy LR, Wiegert RG (eds) Tidemarsh ecology. Springer Verlag, New York, p $69-85$

Munro JL (1982) Estimation of the parameters of the von Bertalanffy growth equation from recapture data at variable time intervals. J Cons Ciem 40:199-200

Negreiros-Franzoso, ML, Franzoso, A (1995) On the distribution of Callinectes ornatus Ordway, 1863 and Callinectes danae Smith, 1869 (Brachyura, Portunidae) in the Fortaleza Bay, Ubatuba, Brazil. Iheringia 79:13-25

Paul RKG (1982) Abundance, breeding and growth of Callinectes arcuatus Ordway and Callinectes toxotes Ordway (Decapoda, Brachyura, Portunidae) in a lagoon system on the Mexican Pacific coast. Estuar Coast Shelf Sci 14:13-26

Pauly D, Gaschuetz G (1979) A simple method for fitting oscillating length growth data with a program for pocket calculators. ICES CM 1979/6:24

Pauly D, Munro JL (1984) Once more on the comparison of growth in fish and invertebrates. Fishbyte 2:21

Pinheiro MAA, Franzoso A, Negreiros-Franzoso ML (1997) Dimensionamento e sobreposiçao de nichos ecológicos dos potunidéos (Decapoda, Brachyura) na Enseada da Fortaleza, Ubatuba, Sao Paulo, Brasil. Rev Bras Zool 14:371-378

Ricker WE (1975) Computation and interpretation of biological statistics of fish populations. Bull Fish Res Board Can 191

Robertson AI, Alongi DM (eds) (1992) Tropical mangrove ecosystems. American Geophysical Union, Washington, DC

Robertson JR, Newell SY (1982a) Experimental studies of particle ingestion by the sand fiddler crab Uca pugilator (Bose). J Exp Mar Biol Ecol 59:1-21

Robertson JR, Newell SY (1982b) A study of particle ingestion by three fiddler crab species foraging on sandy sediments. J Exp Mar Biol Ecol 65:11-17

Rodriguez A, Drake P, Arias AM (1997) Reproductive periods and larval abundance patterns of the crabs Panopeus africanus and Uca tangeri in a shallow inlet (SW Spain). Mar Ecol Prog Ser 149:133-142

Sastry AN (1983) Ecological aspects of reproduction. In: Bliss DE (ed) The biology of crustaceans, vol 8. Academic Press, New York, p 179-270

Shanholtzer SF (1973) Energy flow, food habits and population dynamics of Uca pugnax in a salt marsh system. PhD thesis, University of Georgia, Athens, GA

Smith III TJ, Boto KG, Frusher SD, Giddins RL (1991) Keystone species and mangrove forest dynamics: the influence of burrowing by crabs on soil nutrient status and forest productivity. Est Coast Shelf Sci 33:419-432

Sokal RR, Rohlf FJ (1995) Biometry, 3rd edn. WH Freeman, New York,

Sparre P, Ursin E, Venema SC (1989) Introduction to tropical fish stock assessment. 1. Manual. Fish Tech Paper 306/1. FAO, Rome,

Stearns SC (1976) Life history tactics: a review of the ideas. Q Rev Biol 51(1):3-47

Teal JM (1958) Distribution of fiddler crabs in Georgia salt marshes. Ecology 39(2):185-193

Teal JM (1962) Energy flow in the salt marsh system of Georgia. Ecology 43(4):614-624

Thüllen N (1997) Analyse der Struktur eines Mangrovenwaldgebietes bei Bragança, Nordbrasilien und Untersuchungen ihr zugrundeliegender abiotischer und biotischer Faktoren. Master's thesis, University of Bremen

von Bertalanffy L (1934) Untersuchungen über die Gesetzlichkeiten des Wachstums. 1. Allgemeine Grundlagen der Theorie. Roux Arch Entwicklungsmech Org 131:613-653

Warner GF (1969) The occurrence and distribution of crabs in a Jamaican mangrove swamp. J Anim Ecol 38:379-389

Wessels L (1999) Untersuchungen zur räumlichen Verbreitung bodenlebender Landkrabben (Ocypodidae) in der Mangrove von Bragança, Pará, Brasilien. Master's thesis, University of Bonn

Wiedemeyer W (1997) Analysis of a benthic food web in a mangrove ecosystem at Northeastern Brazil. PhD thesis, University of Kiel

Willson MF, Pianka ER (1963) Sexual selection, sex ratio and mating system. Am Nat 97:405-407

Wolf PL, Shanholtzer SF, Reimold RJ (1975) Population estimates for Uca pugnax (Smith, 1870) on the Duplin estuary marsh, Georgia, USA (Decapoda, Brachyura, Ocypodidae). Crustaceana 29(1):79-91

Wolff M, Koch V, Chavarria JB, Vargas JA (1998) A trophic flow model of the Golfo de Nicoya, Costa Rica. Rev Biol Trop 46(Suppl 6):63-79

Wolff M, Koch V, Isaac V (2000) A trophic flow model of the Caeté mangrove estuary, North Brazil, with considerations of the sustainable use of its resources. Estuar Coast Shelf Sci 50:789-803

Xu X, Mohammed H, Al-Ghunaim A, Al-Yamani F (1995) Temporal variability in natural mortality of green tiger prawns, Penaeus semisculatus, in Kuwait waters. J Shellfish Res 14(2):337-340

Zar JH (1999) Biostatistical analysis, 4th edn. Prentice Hall, Upper Saddle River, NJ 